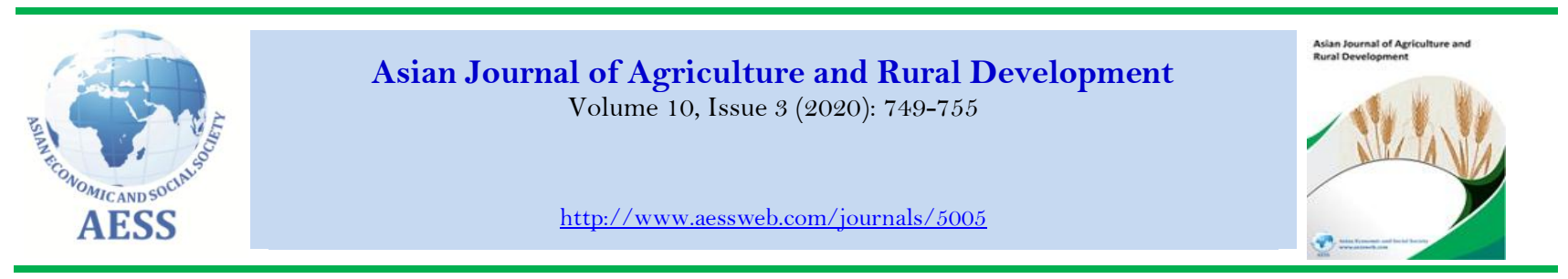

\title{
ECONOMIC ACTIVITIES FOR REPATRIATED MIGRANT WORKERS OF INDIA: A FRAMEWORK FOR RURAL DEVELOPMENT
}

\author{
Sukanta Chandra Swain ${ }^{\mathrm{a}}$ \\ Sunil Kumar Padhi ${ }^{\mathrm{b}}$
}

\section{Article History}

Received: 24 July 2020

Revised: 4 September 2020

Accepted: 6 October 2020

Published: 20 October 2020

\section{Keywords}

Migrant workers

Returnee

Odisha

Rural economy

Agriculture

Skill mapping

Economic activities.
KIIT Deemed to be University, Bhubaneswar, India.
${ }^{\circ}$ Fakir Mohan University, Balasore, India.

- sukantaswain@yahoo.com (Corresponding author)

Contribution/Originality: This study's findings will help policymakers shift their focus from transfer payments to capital overheads. This research will help in policymaking of the management of surplus workers in the rural sector, the management of skill sets of repatriated migrant workers, providing socioeconomic justice to repatriated migrant workers, and weathering the expected recession in the future.

DOI: 10.18488/journal.ajard.2020.103.749.755

ISSN(P): 2304-1455/ ISSN(E): 2224-4433

How to cite: Sukanta Chandra Swain --- Sunil Kumar Padhi (2020). Economic Activities for Repatriated Migrant Workers of India: A Framework for Rural Development. Asian Journal of Agriculture and Rural Development, 10(3), 749-755. 10.18488/journal.ajard.2020.103.749.755

(C) 2020 Asian Economic and Social Society. All rights reserved.

\section{INTRODUCTION}

The Covid-19 pandemic has left its mark across all communities irrespective of their geographical boundaries, but it has made the lives of migrant workers in India wretched and forced most to return to their home regions. The inflow of returnee migrant workers to the rural sector is a crucial concern for the respective state governments (Bhagat, Sahoo, Sahoo, Roy, \& Govil, 2020). The State of Odisha is no exception to this; the lives of migrants from Odisha working in other states are in disarray due to Covid-19. Because of lockdown and shutdown, their work establishments have been closed and they are living in so-called residences where the density of workers per room is exceptionally high. They are obeying the mantra "stay home; stay safe" to help survive the virus, but the nature of 
this incarceration makes them more vulnerable as they cannot maintain social distancing or the required hygiene measures. Since they do not have ration cards, they are deprived of governmental assistance. To safeguard these migrants, the government announced that those establishments where migrants are working would take care of their food and other basic requirements.

However, it is obvious that the reality of their conditions is far removed from that stated by the government. When these establishments are no longer operational and showing a negative return on investment, how long can they support those workers? Consequently, migrant workers are left either starvating or poorly fed. They are unable to return to their home villages because no mode of transportation is allowed during lockdown. Also, they are well aware that they will be put into quarantine for 14 days in their villages and, only if everything goes well post quarantine, will they be allowed to enter their village and residence. In both cases, they are facing a critical choice between life and livelihood. In the former case, as they walk for long distances looking for work in their native villages, they put their lives at risk owing to the physical strain of extensive walking and their vulnerability to Covid19. In the latter case, if they seek work outside of their local area, they render themselves vulnerable to the virus (Jan, 2020). This is a matter to ponder for researchers and planners - life or livelihood, which is to be prioritized during this unprecedented situation, particularly for migrant workers? Is there any intermediate pathway for these migrants? That question is the basis of this research proposal for the design of a comprehensive framework. One clue to the solution of this question, and which encompasses a greater socioeconomic issue, has been arrived at by analysis of the literature, in both print and electronic media.

India's government has started to announce economic packages for different sectors of the economy and different sections of society. These packages may help address the employment issues in both segments regarding migrant workers during the post-pandemic situation. These packages announced by the government, together with existing facilities and those to be created in rural areas, may address the issue of tackling the surplus workforce that has emerged due to repatriation of migrant workers. However, the value paradox still stands because migration was the outcome of not accommodating the rural population effectively in their home regions; but how will this rural economy accommodate the returnee migrants? A well-thought out framework devised by the government may address this paradox. Thus, the development of a precise framework is needed to efficiently utilize this surplus workforce by proper planning for the skill sets inherent in migrant workers and the facilities available or created in rural areas (Singh, Patel, Chaudhary, \& Mishra, 2020).

As a rough estimation, of around 2 million migrant workers from Odisha working in different states around the country, more than 0.5 million have returned to Odisha. These migrant workers are an extra burden on the rural sector as they return to their place of origin. If they are properly utilized, the primary sector, in particular, and the rural economy, in general, may see a boost in regard to growth and development. However, improper utilization of this additional workforce may create chaos and distortion in the rural economy.

The immediate measures required of the state are:

Food security: the government and many nongovernmental organizations (NGOs) have put all their efforts into providing food security to all migrants. Thus, there must be a team set up to ensure implementation along the desired pathway.

Agricultural labour security: the addition of repatriated migrant workers to the existing workforce in rural areas may result in a surplus workforce, which will overload the agricultural sector leading to hidden unemployment.

The leading existing economic activity that dominates provision of livelihoods in the rural sector of Odisha is agriculture. Of the 15.57 million hectares comprising the geographical area of Odisha, $41.16 \%$ is cultivable. The average holding is 1.25 hectares, and $83 \%$ of farms are small and marginal. Agriculture employs around $65 \%$ of the state workforce and contributes around $26 \%$ of state GDP.

Due to various factors such as baffling soil (waterlogged, acidic, and saline), absence of assured irrigation, lowlevel seed transposition, basal levels of fertilizer usage, and reduced pace of mechanization, agriculture in Odisha is known for its low productivity. The very poor yield potential and technology transfer provide an opportunity for the state to increase production and productivity substantially.

For the effective utilization of repatriated migrants, all rural sector stakeholders need to make a concerted effort to solve the current problem of accommodating them in economic activities and facilitating development of the rural economy.

From secondary data, i.e., data from the registration documents of returnee migrants, we can assess the baseline for the type of employment under consideration. Before assessment of the skills of returnee migrant workers, we should compile a list of parameters that cover the expertise of workers inherent in each job ascertained from the secondary data. If a particular job is not found in the migrants' register, it could possibly be created in the locality. The parameters inherent in that job will also be enlisted as that could be a source of employment for some migrants after motivating and making them trained.

\section{LITERATURE REVIEW}

Repatriation of migrant workers could become an important lever for development. The knowledge, skills, and expertise gained in the workplace are channeled into the production process and appropriate institutional infrastructure (Kumar, Bhattacharya, \& Nayek, 2014). There have been policy issues in regard to the rehabilitation of repatriated migrants from Gulf countries to India; lack of a comprehensive framework to channel those returnees is responsible for them not becoming contributors to domestic growth (Kumar, 2008). While chronic poverty is the cause of migration in most cases, migration may lead to chronic poverty in exceptional cases due to an incorrect approach (Kothari, 2002). Apart for decentralization, the convergence of various services related to food and 
nutritional programmes, water and sanitation programmes, and employment and livelihood programmes must be made worthwhile. It is appropriate to establish an alliance and systematization between central and state governments (Bhagat et al., 2020).

Around $31 \%$ of the workers surveyed reported they had taken loans from banks, moneylenders, contractors, or other sources, and $8 \%$ said they had taken loans from multiple sources. More than $79 \%$ believed that they would not repay their debts in the short term, and nearly 50\% feared danger or violence due to their inability to repay these debts. Over $42 \%$ of the workers surveyed said they did not have sufficient rations for the next day, while nearly $40 \%$ said they had rations for the next two weeks and $18 \%$ reported that they had enough for $2-4$ weeks. One third (33\%) of the workers surveyed reported having no money to buy rations, $14 \%$ had no ration card, and $12 \%$ had ration cards. Nevertheless, these workers could not access the public distribution system because they were migrants (Jan, 2020).

Return migration has many potential benefits. Through employment abroad, migrants can increase their income, acquire new skills, and accumulate savings and assets. However, benefits are materialized in their home region only if that region has the right policies to encourage returnees' investment and to use their skills (Wahba, 2015). Return migration has major potential to boost the performance of the economic engine of the country. However, it needs to be handled delicately (Dustmann \& Weiss, 2007). Returnee migrants have experienced both a conservative and an innovative approach.

Returnee migrants use their earnings generated for repayment of loans previously taken, or to meet family needs in some cases. This is the conservative approach. In other cases, returnee migrants use their return to develop a new career (Kļave \& Supule, 2019).

Based on a comparative study in six countries, it was found that return migration has the potential to engender peace and prosperity. Migrants intend to be the agents of positive change in their home territory (Houte \& Davids, 2014). With governmental policies and assistance from NGOs, a relationship among repatriated migrants, sustainability, and growth can be established. A borderless approach is needed to address the need for repatriated migrants, strengthening the economic condition of the regions where they are based (Van \& Davids, 2008). Migration has the potential to impact economic development because repatriated migrants can promote entrepreneurship in their place of origin. By way of ethnographic research in Senegal among repatriated entrepreneurs, it was found that return migration is a pivotal instrument for promotion of development (Sinatti, 2019).

Return migration is a key component of total migration, because it is estimated that approximately one in four returnee migrants relocates to their place of origin. Returnee migrants, if organized properly, may drive the local economy in the desired direction (Azose \& Rafterya, 2019). By contributing to social reclamation and economic growth, returnee migrants can contain ferocity in their places of origin. In the context of homicide rates in Mexico, it was found that the higher the rate of return migration the lower the local homicide rate (Bucheli, Fontenla, \& Waddell, 2019).

While migration is treated as a brain drain, return migration can be seen as a brain gain (Olesen, 2002). Returnee migrants promote entrepreneurship and the generation of capital, both financial and human, in their place of origin. However, proper planning must integrate the inherent talent and intent of returnee migrants with the local economies (Coniglio \& Brzozowski, 2018). A concise framework based on reviews of experiential and theoretic literature on the economic development role of repatriated migrants is required (Wahba, 2014).

It is apparent from the literature reviewed here that return migration has great potential to contribute to the economy. Nevertheless, this requires planned intervention with a comprehensive framework to channel that potential. This research is primarily designed to develop an all-encompassing framework for the same.

\subsection{Objectives}

The objective of this study was to design a framework that includes the following:

The wishes of migrant workers concerning their place of work after the restoration of normality.

All potential work opportunities (available and future) in rural areas.

The potential of migrant workers' to adapt to any job that is available or that can be created in their native region. Mapping of job opportunities in the locality with regard to the potential of migrant workers, by absorbing the surplus workforce efficiently and thus benefitting the rural sector.

\section{METHODOLOGY}

The framework and proposed methods for the research are given below.

The study is a blend of descriptive and action research for rural Odisha. The census method (i.e., complete enumeration survey) was followed. Both primary data (from repatriated migrants, villagers, village heads, experts, and established repatriated migrants) and secondary data (analysis of both the print and digital literature) were used.

To outline all potential work opportunities and explore some unusual and unconventional work opportunities based on existing facilities and available know-how, regular and sustainable livelihoods could be catered for.

Content analysis and experts' opinions are used to design a model that absorbs a surplus workforce to benefit the rural economy.

Descriptive statistics are used to interpret data, and a skills matrix created to assess the skill sets of repatriated migrant workers, which will be mapped with existing and would-be job opportunities created. 


\subsection{Efforts to Accommodate Repatriated Migrants}

To upgrade the skills of returnee migrants and to create sustainable livelihood opportunities under the Pradhan Mantri Kaushal Vikas Yojana and the Apprenticeship Scheme, the Skill Development Ministry of India selected 116 districts of the country to reskill as per local requirements. The Ministry will identify the current skill sets of returnee migrants and reskill them, if necessary, as per local job market requirements.

It is pertinent that skill mapping and reskilling are addressed without delay to ease the pressures on the rural economy created by returnee migrants. However, skill mapping methodology is vital but has not been clarified by the Skill Development Ministry. Our focus is on the methodology for skill mapping.

In Bihar, the Department of Industry carried out skill profiling of 80,000 returnee migrant workers and found that most were unskilled. Hence, Bihar is planning to focus on the Mahatma Gandhi National Rural Employment Guarantee Act (MGNREGA) to provide livelihoods to unskilled migrant workers at an enhanced workday of 200 from 100 previously.

However, the potential of reskilling those unskilled workers who intend to engage in other modes has not been explored; our skill profiling methodology and recommendations for reskilling will create a window of opportunity for those unskilled workers.

The state of Uttar Pradesh has begun to liaise with industry to accommodate skilled and semiskilled returnee migrants. Real estate companies have already started contacting such workers for skill assessment, based on which they will be accommodated or, if required, they will be reskilled before being accommodated. However, the problem here concerns correct skill profiling and interest assessment. Perhaps skill profiling will be done apropriately by the real estate companies, but what about workers' intentions? Real estate companies are mostly based in cities, but returnee migrants live mostly in their home villages. In this case, migration would again occur from rural to urban areas in that state but not in other states. The Covid-19 pandemic has impoverished the lives of migrants within the state, as well as the resident population. Thus, mere skill profiling is insufficient to address the issue. Besides skill profiling, intent assessment is required because most returnee migrants may prefer to remain in their native areas.

Moreover, the real estate sector may have little spare capacity to accommodate a substantial additional workforce. At present, people in cities also struggle to find regular work. If accommodating returnee migrants results in redundancy for existing workers, this is clearly not a solution. Finding a way to accommodate returnee migrants in their native regions will solve the problems of ignoring their wishes, reduce the incomes of existing workers in cities and strengthen the rural economy. Our framework is aimed at addressing this gap.

Jharkhand and Odisha are in a similar position to Uttar Pradesh, with pivotal dependence on MGNREGA. However, this is not the right platform for skilled and semiskilled returnee migrants. A pertinent point that questions the potential of MGNREGA is: "Can it generate sufficient work for massive numbers of returnee migrants or will it just be a type of transfer payment to inject money into the economy?"

States like Punjab and Haryana have adopted a different approach. Migrants working in those two states and who were unable to return to their native regions because of lockdown were given distress cards by which they can obtain free food (grain) until they resume work. Some migrant workers who had gone back to their native regions were offered booked train tickets by their employers to return to work. However, considering the pain and fear the migrant workers experienced because of the Covid-19 pandemic, it is important to assess their wishes. Nevertheless, unfortunately, migrant workers' wishes have not been given due importance in either of the alternatives mentioned.

Although efforts made to date at different levels to accommodate returnee migrants in economic activity are undoubtedly praiseworthy, the outcome will be satisfactory only if they are properly channeled through skill mapping.

\subsection{Skill Mapping through Skills Matrix}

The following steps were used to map the skills of returnee migrants.

Identify all possible work opportunities in rural areas (an exhaustive list can be prepared).

Considering the specific conditions in Odisha, work opportunities could be created through the following suggested categories: traditional farming (rabi and kharif crops), horticulture, vegetable farming, mushroom farming, sugarcane farming, betel leaf plant farming, floriculture, animal husbandry (cattle, sheep, goats, and pigs), beekeeping, poultry, fishery, masonry, brick making, trading in agricultural products, cottage industries (based on locally available raw materials), vehicle repair, pottery, carpentry, blacksmith work, goldsmith work, stationery shop, snack shop/dhaba, tailoring, painting, plumbing, electrical work, welding, security guarding, and see-saw, rice, and flour milling, etc. However, the complete list of job opportunities for a particular locality may vary depending on soil quality, climatic conditions, availability of raw materials, etc. Further, each category of work opportunity needs to be tested for its potential to accommodate an enhanced workforce; otherwise, it may create hidden unemployment.

Define the relevant skills required for each job opportunity (enumerate all skills required for each job opportunity.

For example, to establish a successful career in horticulture, knowledge of the following is required:

- Irrigation

- Plant nutrition

- Soil management

- Crop rotation

- Pest and disease management

- Weed control 
- Care in postharvest handling

- Costs involved in machinery and equipment, etc.

- Adopting technology as and where required

- Legal aspects of food safety requirements

- Dealing with people, i.e., good interpersonal skills.

Any migrant with the qualities of crop cultivation knowledge, basic education, willingness to learn, dedication, patience, good communication skills, and interest in horticulture can be reskilled to adopt this area as his/her occupation.

Assess repatriated migrants on their current skill levels.

For each job we need to know the migrant's level of proficiency, which is scaled thus:

- No experience or knowledge (level 1)

- $\quad$ Little experience or knowledge (level 2)

- Reasonable experience or knowledge (level 3)

- Considerable experience or knowledge (level 4)

- Expert experience or knowledge (level 5).

Migrants are to be briefed about the skill set or proficiency required for each job so that they can rate themselves appropriately.

Determine a migrant's interest in working in their chosen field. For each migrant, we would want to know whether they are:

- Not interested in applying their skills or knowledge in this job (level o)

- Interested in applying their skills or knowledge in this job (level 1).

Information collected from steps 3 and 4 will help us to create 'clusters' of returnee migrants.

Assimilate all data collected from steps 1 and 2 in the skills matrix.

The format of the skills matrix, showing the levels of proficiency and interest of returnee migrants in regard to a specific type of work, is presented in sample form in Table 1. This will be extended for all types of work identified in the locality.

\begin{tabular}{|c|c|c|c|c|c|c|}
\hline \multirow{3}{*}{$\begin{array}{l}\text { Proficiency } \\
\text { rating }\end{array}$} & \multicolumn{2}{|c|}{ Past employment } & \multicolumn{4}{|c|}{$\begin{array}{l}\text { Level of proficiency and interest of migrant } \\
\text { regarding different work opportunities }\end{array}$} \\
\hline & \multirow{2}{*}{$\begin{array}{l}\text { What } \\
\text { (where) }\end{array}$} & \multirow{2}{*}{ Expertise } & \multicolumn{2}{|l|}{ Horticulture } & \multicolumn{2}{|c|}{ Mushroom farming } \\
\hline & & & Proficiency & Interest & Proficiency & Interest \\
\hline \multicolumn{7}{|l|}{1} \\
\hline \multicolumn{7}{|l|}{2} \\
\hline \multicolumn{7}{|l|}{3} \\
\hline \multicolumn{7}{|l|}{4} \\
\hline 5 & & & & & & \\
\hline
\end{tabular}

Table 1 is a sample of the skills matrix in which only two employment opportunities are featured. However, while collecting data from migrants, all work opportunities will be reflected in the matrix. When administering this schedule to migrants, the data collector must clarify all its technicalities.

Take action on insights derived from the skills matrix.

Migrants will be clustered according to the output of the skills matrix and accordingly reskilled, if required, to be accommodated by any of the work opportunities. For example, suppose a migrant has rated her/himself 1 for proficiency and o for interest under each work opportunity; in that case, s/he may be considered for unskilled work through MGNREGA or as a casual worker in traditional farming as per the requirements. If a migrant reveals a degree of proficiency in a particular type of work and shows interest in that job, s/he may be considered for the said job. Suppose a migrant shows interest in multiple jobs and has different levels of proficiency in those; in that case, $\mathrm{s} /$ he will be accommodated in the type of work in which his/her proficiency level is highest. Migrants having a reasonable level of proficiency, or the highest level of proficiency for them personally, will be directly accommodated in that job where available. On the contrary, migrants with a low proficiency level, which is the highest level of proficiency for them personally, will be upgraded through reskilling before being accommodated in that job.

\section{CONCLUSION}

Migration plays a crucial role in maintaining a balance between the twin market forces of demand and supply in the inter-regional labour market. The research in this study is innovative; it advocates accommodating surplus labour emerging from the repatriation of migrant workers to their native regions. This research is not meant to discourage migration; rather, it targets a solution for managing pressure in the labour market of rural areas where migrant workers are being repatriated due to disruption to their lives resulting from the Covid-19 pandemic, with no intention on their part to migrate again even after normality is restored. This research was planned to effectively 
manage a surplus workforce in rural areas to benefit the rural economy. It was designed to solve the socioeconomic issues of repatriated migrants and the overall development of the rural economy.

This study's basic objective was to design a framework to accommodate a surplus workforce returning permanently to their native regions from their previous workplaces. As such, the rural sector is not able to accommodate them efficiently with the facilities currently available; pump priming (stimulating economic activity through investment in socioeconomic overheads) is required to get them effectively engaged. Capital overheads will be created, and self-employment will be promoted by way of providing subsidies and facilitating acquisition of the required know-how. This, in turn, will enable the rural sector to prosper and the rate of employment in the rural economy will be expanded. Greater employment will accelerate the purchasing power of the community and augment the supply of goods and services. Thus, society will be in equilibrium at a higher level.

This study's findings will help policymakers shift their focus from transfer payments to the creation of capital overheads. Instead of providing free or very subsidized essential commodities in creating socioeconomic justice in the rural sector, policymakers can provide the subsidized equipment required for job opportunities that will accommodate repatriated migrant workers and add enormous value to the rural economy. However, transfer payments in the form of either cash or in kind might make the rural population complacent, and there is a risk that they could opt for working less in the hope of being taken care of by the government for their essential needs. Thus, pump priming represents a better alternative than transfer payments and, as such, it has the inherent trait of combatting recessionary pressure which is part of the post-COVID-19 effect. Thus, this research will help policymaking in regard to 1) management of a surplus workforce in the rural sector, 2) management of the skill sets of repatriated migrant workers, 3) providsion of socioeconomic justice to repatriated migrant workers, and 4) combatting the anticipated recession.

Funding: This study received no specific financial support.
Competing Interests: The authors declare that they have no competing interests.
Acknowledgement: Both authors participated equally in the design and estimation of th
ecurrent research.
Views and opinions expressed in this study are the authors' views and opinions; the Asian
Journal of Agriculture and Rural Development shall not be responsible or answerable for any
loss, damage, or liability, etc. caused in relation to/arising out of the use of the content.

\section{REFERENCES}

Azose, J. J., \& Rafterya, A. E. (2019). Estimation of emigration, return migration, and transit migration between all pairs of countries. PNAS, 116(1), 116-122. Available at: https://doi.org/10.1073/pnas.1722334116.

Bhagat, R. B., Sahoo, H., Sahoo, A., Roy, K., \& Govil, D. (2020). The COVID-19, migration and livelihood in India. Paper presented at the A Background Paper for Policy Makers, International Institute for Population Sciences, Mumbai.

Bucheli, J. R., Fontenla, M., \& Waddell, B. J. (2019). Return migration and violence. World Development, 116, 113-124. Available at: https://doi.org/10.1016/j.worlddev.2018.12.010.

Coniglio, N. D., \& Brzozowski, J. (2018). Migration and development at home: Bitter or sweet return? Evidence from Poland. European Urban and Regional Studies, 25(1), 85-105. Available at: https://doi.org/10.1177/0969776416681625.

Dustmann, C., \& Weiss, Y. (2007). Return migration: Theory and empirical evidence from the UK. British Journal of Industrial Relations, 45(2), 236-256. Available at: https://doi.org/10.1111/j.1467-8543.2007.00613.x.

Houte, M. v., \& Davids, T. (2014). Moving back or moving forward? Return migration, development and peacebuilding. New Diversities, 16(2), 71-87.

Jan, S. (2020). Voices of the invisible citizens: a rapid assessment on the Impact of COVID-19 Lockdown on Internal Migrant Workers. April, New Delhi.

Kḷave, E., \& Supule, I. (2019). Return migration process in policy and practice. In: Kaša R., Mierina I. (eds) The Emigrant Communities of Latvia. IMISCOE Research Series. Cham: Springer.

Kothari, U. (2002). Migration and chronic poverty. Working Paper No. 16, Chronic Poverty Research Center, Institute for Development Policy and Management, University of Manchester.

Kumar, P. (2008). Gulf return migration and dilemmas of rehabilitation: Policy issues in India. New Delhi: Icon Publications Pvt. Ltd.

Kumar, P., Bhattacharya, U., \& Nayek, J. K. (2014). Return migration and development: Evidence from India's skilled professionals. G. Tejada et al. (eds.), Indian Skilled Migration and Development, Dynamics of Asian Development.

Olesen, H. (2002). Migration, return, and development: An institutional perspective. International Migration, 40(5), 125-150. Available at: https://doi.org/10.1111/1468-2435.00214.

Sinatti, G. (2019). Return migration, entrepreneurship and development: Contrasting the economic growth perspective of Senegal's diaspora policy through a migrant-centred approach. African Studies, 78(4), 609-623. Available at: https://doi.org/10.1080/00020184.2018.1555310.

Singh, S. K., Patel, V., Chaudhary, A., \& Mishra, N. (2020). Reverse migration of labourers amidst COVID-19. Economic \& Political Weekly, 55(19), 28-31. 
Van, H. M., \& Davids, T. (2008). Development and return migration: From policy panacea to migrant perspective sustainability. Third World Quarterly, 29(7), 1411-1429. Available at: https://doi.org/10.1080/01436590802386658.

Wahba, J. (2014). Return migration and economic development. Chapters, in: Robert E.B. Lucas (ed.),International Handbook on Migration and Economic Development (pp. 327-349). Edward Elgar Publishing.

Wahba, J. (2015). Who benefits from return migration to developing countries? Working Paper, University of Southampton, UK, and IZA, Germany. 